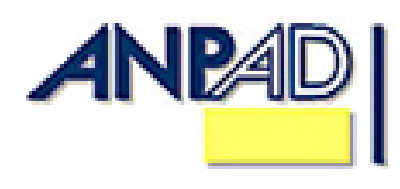

Available online at http://www.anpad.org.br/bar

BAR, Rio de Janeiro, v. 11, n. 1, art. 2, pp. 22-46, Jan./Mar. 2014

\title{
Productivity Spillovers from Foreign Direct Investment in the Brazilian Processing Industry
}




\begin{abstract}
The increasing importance of foreign direct investment (FDI) to international production has prompted considerable interest in its real effects on host economies all over the world. The aim of this study was investigate whether the presence of FDI produces productivity spillovers in Brazilian processing industries. We conduct our analysis using a panel database on twenty-three Brazilian processing industries and applied Moderated Multiple Regression (MMR) and Generalized Linear Models (GLM) analysis of variance to address potential spillover effects from foreign presence. This paper finds evidences of the coexistence of both positive and negative effects arising from FDI on the productivity of Brazilian industries. We found negative effects for FDI presence in labor-intensive industries. Furthermore, FDI benefits depend on the absorptive capacity of industries, confirming the hypothesis that a minimum level of absorptive capacity is required so that locally owned enterprises (LOEs) can benefit from foreign presence.
\end{abstract}

Key words: foreign direct investment; productivity spillovers; manufacturing Industry; Generalized Linear Models; absorption capacity. 


\section{Introduction}

Although the attitudes towards the impacts foreign direct investment (FDI) has on the host economy have been mixed, many governments around the world actively attempt to attract FDI to their countries using substantial fiscal and financial incentives. One of the reasons for these policy interventions is the belief that locally owned enterprises (LOEs) can benefit from the foreign owned enterprises (FOEs) through productivity spillovers (Görg \& Greenaway, 2004).

Productivity spillover discussion is part of a broad debate on the effects arising from FDI's inflows and the presence of multinational corporations (MNCs) in the host economies (Blomström \& Kokko, 1998; Buckley, Clegg, \& Wang, 2010; Findlay, 1978; Markusen \& Venables, 1999). FDI and multinational corporations (MNCs) are subtly different facets of the international phenomenon, but are not perfectly synonymous (Cohen, 2007, p. 36). A widely accepted concept of MNCs in academic and business circles considers them an enterprise that engages in FDI activities and "owns or, in some way, controls value-added activities in more than one country". MNCs account for almost all FDI flows (Kupfer \& Hasenclever, 2002, p. 391) and are the main cause of the major changes in the way that business is conducted throughout the world (Cohen, 2007).

Productivity spillover theory is based on the argument that FDI occurrence requires MNCs to be more efficient than their indigenous counterparts operating in the same location (Buckley, Clegg, \& Wang, 2010). So, firm-specific assets, such as marketing and management capabilities, technological know-how and reputation, that play important roles in Dunning's traditional Eclectic FDI theory $(2000,2008)$ are fundamental to the argument that MNC ownership advantages should lead to relativity higher performances than their counterparts. This notion of "performance differentials is the basis for the general hypothesis that FDI generates productivity spillovers" (Buckley, Clegg, \& Wang, 2010, p. 217). Blomström and Kokko (1998) comments that, when MNCs establish a subsidiary in certain countries, they bring a series of new knowledge and technologies that can spill over for LOEs, resulting in competitiveness increases and productivity gains, known as productivity spillovers.

This study aims to answer the following research question: Are there productivity spillover effects from FDI received by the Brazilian processing industries? Our intention is to contribute to the discussion on FDI's real impacts, assessing whether the FDI received by the Brazilian processing industries contributed to their performance. In other words, the main objective of this research was to investigate if there were productivity spillovers effects from FDI received by Brazilian processing industries. Specifically we aimed to: (a) investigate the effects of a set of variables representing the characteristics of the industry and characteristics of the country on industry productivity; and (b) investigate the moderating effect of FDI on industry productivity.

We also conduct our analysis using a panel database of twenty-three Brazilian processing industries. We applied the Moderated Multiple Regression (MMR) and Generalized Linear Models (GLM) analysis of variance to address potential spillover effects from foreign presence.

Our main purpose in this study is not to identify with either the pro or con schools of thought on the subject, but to share our belief that both sides have made valid points on the subject. The paper highlights, as argued by Cohen (2007), that each corporation and each industry or country is a special case and that FDI is an extremely complex and heterogeneous phenomenon. It's not our intention to reach a conclusion to the question of whether these phenomena are good or bad, but to add to our far from comprehensive knowledge of what are FDI effects and how they really affect the productivity of Brazilian industries. Only a few studies have considered how the relationship between foreign presence and spillover benefits change as inward FDI to Brazilian industries rises, and little attention has been given to the conditions under which spillover might be larger, non-existent or negative (Cohen, 2007).

The solid understanding of the FDI role on the host economy is vital not only for researchers but also policymakers and managers interested in understanding how FDI inflows influence industry 
performance. Given their dynamicity and complexity, FDI and MNC phenomena have introduced extraordinary and perhaps revolutionary changes that have profoundly altered the global economy.

Policymakers in particular need information that provides them with the necessary tools for the decision making process. They influence the regulatory regime in which MNCs and LOEs are embedded and, therefore, need to understand how policy instruments can induce or control MNC actions so that they can offer benefits to LOEs. MNC effects on host economies is also relevant for managers. First of all, positive effects of spillovers can be used to build a reputation, since companies are concerned with stakeholders. Second, recognizing complementary interests and areas of conflict helps identify strategies that benefit both MNCs and LOEs in host economies.

Our main contribution is not providing a definite explanation on the issue. It is, however, just a step in a long journey to a more accurate understanding on the subject. There still remains a need for continuing the research and data accumulation in this field (Cohen, 2007).

This paper's structure is organized as follows: the next section presents the evolution of FDI inflows to the Brazilian economy. Third section presents the theory of spillovers from FDI, while fourth section clarifies the conceptualization and operationalization of FDI spillover determinant factors, which is followed by a presentation of our methods and data in fifth section. Sixth section presents the empirical results and seventh section presents the discussions. The last section offers final considerations.

\section{Foreign Direct Investment Trajectory}

Until the Second World War, only a small portion of capital movement was related to FDI. FDI global flows had suffered a slump in the 1970s related mainly to the oil shock and macroeconomic crises. The decline in FDI global flows in the 1970s and 1980s was interrupted by a reaction in the early 1990s, when FDI flows became really significant. In 1990, FDI flows worldwide were approximately $\$ 200$ billion, reaching their maximum level at the end of the decade, in 2000 , when flows reached \$ 1.4 trillion (Figure 1).

After this global boom, FDI flows fell to $\$ 651$ billion in 2002, approximately half the value that was reached in the peak period in 2000 (United Nations Conference on Trade and Development [UNCTAD], 2003). 


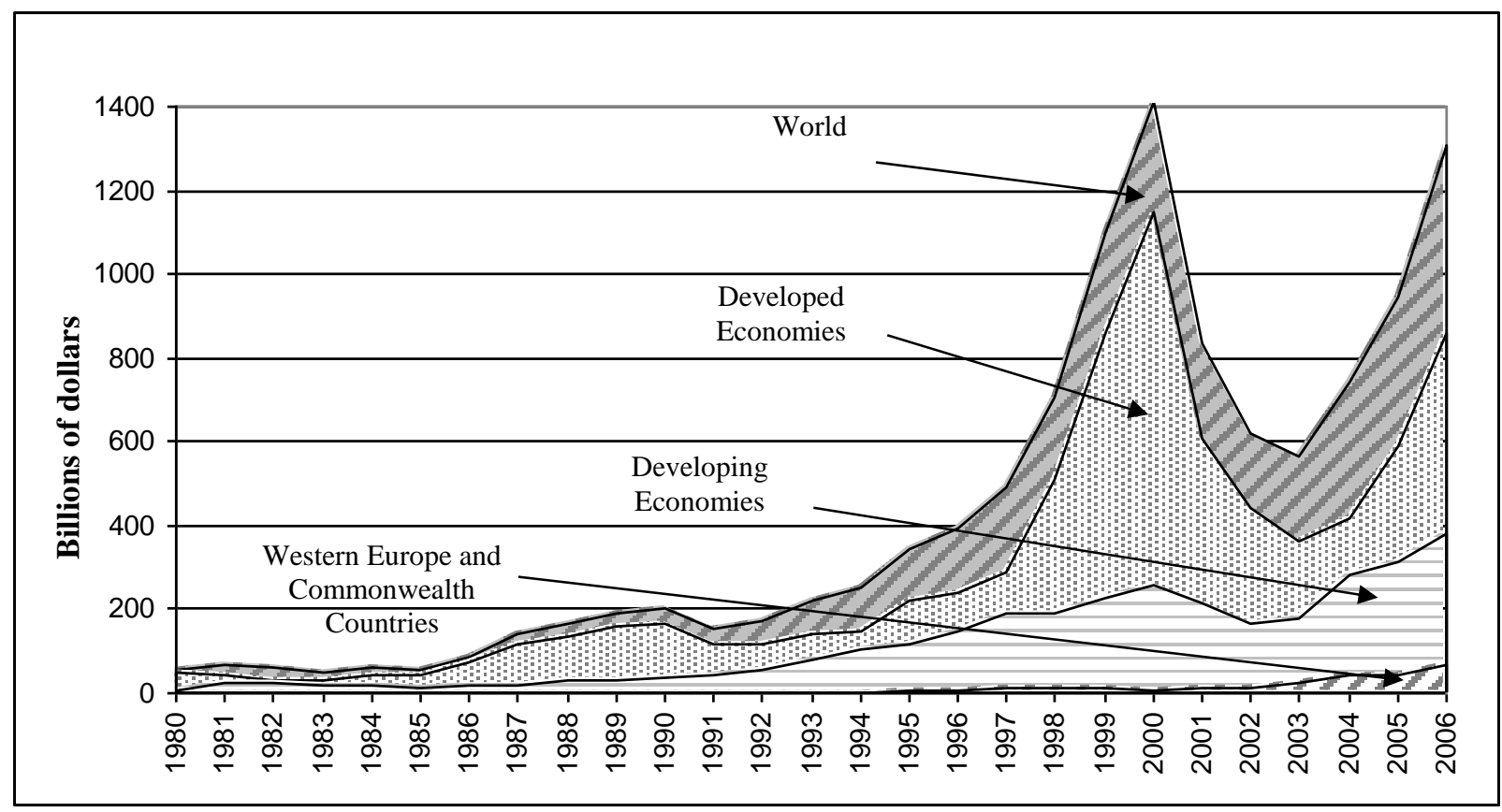

Figure 1. FDI Flows Worldwide and by Groups of Economies, 1980-2006 (billions of dollars).

Source: United Nations Conference on Trade and Development. (2007, outubro). Crescimento pulverizado do investimento direto estrangeiro em 2006. Anais da Conférence des Nations Unies Pour le Commerce et le Développement, Geneva, Switzerland.

FDI global flows began to increase again in 2003 and in 2006 accumulated \$1.306 billion, an increase of over $38 \%$ compared to the previous year, reaching levels close to those reached in 2000 (UNCTAD, 2007). FDI inflows increased in all three groups of economies, reflecting the propensity of growth of multinational corporations (MNCs) and favorable economic performance in many parts of the world. While in developed countries FDI reached $\$ 857$ billion in 2006 (a growth of $45 \%$ over the previous year), the flow reached its highest levels in developing countries and economies in transition. The flows in developing countries accumulated $\$ 379$ billion, representing an increase of $21 \%$ over 2005 , while the flows to transition economies reached $\$ 69$ billion, representing an increase of $68 \%$ compared to 2005 (UNCTAD, 2007).

The major sources of FDI were MNCs from developed countries, especially the European Union (EU). MNCs from developing countries and economies in transition continued their international expansion, led by China (UNCTAD, 2007).

The flows of FDI into Brazil started primarily during the 1955 - 1960 period, when specific governmental programs were created to attract foreign capital as strategy for industrial development through import-substitution industrialization. In the 1970s, the amount of capital went down, mainly due to the oil shock associated with macroeconomic crisis.

The 1970s were characterized by a large FDI inflow into the Brazilian economy. The main determinants of the FDI supply abundance were related to economic growth orientation and a nondiscriminatory foreign capital police consolidation. During the 1980s, there was a reversal of capital flows, essentially from the lack of credibility due to non-accomplishment of external obligations, economic instability and increased uncertainty associated with anti-inflationary plans. Starting in the 1990s there was an extraordinary recovery of FDI flow growth, reflecting the financial globalization effects and mergers and acquisitions (M\&A) possibilities due to the opening and privatization of the Brazilian economy (Fernandes \& Campos, 2008).

The Brazilian economy experienced a boom in FDI flows in 2000. After this period, FDI flows to the Brazilian economy decreased, following the world's FDI behavior, but also reflecting the inexpressive Brazilian economy's growth and the end of the privatization phase that marked the 90s. In 2004, there was a reaction to FDI inflows and, according to the United Nations Conference on 
Trade and Developmen (UNCTAD, 2007), FDI to the Brazilian economy had the highest increase rate in the world in 2007 (from $\$ 18.8$ billion in 2006 to $\$ 37.4$ billion, representing an increase of $99.3 \%$ ). This new record surpassed 2000, when FDI inflows reached $\$ 32.8$ billion, and $22 \%$ of the total amount of FDI inflows were related to privatization operations. The new record occurred even without privatization operations, reinforcing the significance of the record reached in 2007.

The upward movement of FDI in the Brazilian economy in recent years occurred simultaneously with appreciation of the Real ( $\mathrm{R} \$$, the Brazilian currency), which might seem paradoxical, since domestic currency appreciation makes Brazilian assets more expensive, as well as the cost of inputs, raw materials and components needed for multinational subsidiaries operation maintenance. However, what is observed is that Real appreciation didn't affect FDI inflows as one might imagine. In fact, Real appreciation in recent years is not a result of passing situational factors, but rather sustained improvement in Brazilian fundamentals that fosters predictability over the longerterm horizon (Sociedade Brasileira de Estudos de Empresas Transnacionais e da Globalização Econômica [Sobeet], 2007).

\section{Theory of Spillover from Foreign Direct Investment}

Productivity spillover effects from inward FDI are usually defined as "the influence of the presence of foreign-owned enterprises (FOEs) on productivity of LOEs" (Buckley, Clegg, \& Wang, 2010, p. 193). They are generated by non-market transactions involving MNCs, in particular when knowledge is spread to LOEs of the host country without a contractual relationship (Buckley, Clegg, \& Wang, 2010; Meyer, 2004).

In the literature on FDI spillovers, it is argued that MNCs that establish subsidiaries in other countries are different from LOEs in the receiving economy market for two main reasons. The first is that they bring with them superior knowledge about foreign markets (Caves, 1971) and certain technological properties that constitute their specific advantages that allow them to compete with other MNCs and local firms that usually have better knowledge of local market and consumer preferences (Aitken, Harrisson, \& Lipsey 1996; Blomström \& Kokko, 1998). The second reason is that the entry or presence of MNCs alters existing market equilibriums, forcing local firms to become more efficient to protect their market shares and profits (Blomström \& Kokko, 1998).

Firm-specific assets, such as marketing and management capabilities, technological know-how and reputation, that play important roles in Dunning's traditional Eclectic theory of FDI (Dunning, 2000; Dunning \& Lundan, 2008), are fundamental to the argument that MNC ownership advantages should lead to relativity higher performances than their counterparts. This notion of performance differentials is the basis for the general hypothesis that FDI generates productivity spillovers (Buckley, Clegg, \& Wang, 2010; Thang, 2011).

According to Caves (1974), the beneficial effects of FOEs can be summarized in terms of: (a) allocative efficiency gains that arise from pro-competitive effects; (b) technical efficiency improvements from demonstration of superior practices; and (c) technology transfer when the presence of FOEs furnishes LOEs with access to advanced technology. Therefore, spillover effects can be reflected in improved productivity and other benefits in LOEs (Buckley, Clegg, \& Wang, 2010).

Spillover theory states that industry and country specificities have a strong relationship with spillover occurrence. It suggests that there is a high degree of heterogeneity across industries due to learning capabilities and technologies absorbing capacity differences. Moreover, changes in macroeconomic policies have different impacts across industries. In this sense, best performing industries offer better innovations and new knowledge absorption conditions that make LOEs in a host country more competitive. If LOEs are able to offer strong competitive relationships with MNCs, then 
they will find themselves forced to constantly change their techniques, transferring their technologies more frequently than could be imitated by LOEs (Gachino, 2010).

However, a number of negative spillovers effects have been put forward recently with the argument that negative effects start to become apparent when greater levels of foreign presence begin to counteract the positive effects on LOE productivity. According to Aitken and Harrisson (1999), this may occur since FOE affiliates may draw demand away from their counterparts through the introduction of new products and innovation processes leading to price reductions (Aitken \& Harrison, 1999). For this reason, there are some potential costs associated with FDI, such as the emergence of concentrated market structures that may compromise the development of competitive markets (Appleyard \& Field, 1998; Blomström \& Kokko, 1998).

\section{Conceptual Model and Hypothesis}

Pioneer studies on FDI spillovers came from Caves (1974) for Australia, Globerman (1979) for Canada, and Blomström (1986) for Mexico. They found a positive relationship between foreign presence and labor productivity, implying that foreign presence had a positive influence on productivity (Gachino, 2010). These studies have since been developed and refined, but the basic approach remains (Görg \& Greenaway, 2004).

Most econometric analysis use a framework that regresses the labor productivity or the total factor productivity of firms on a range of independent variables. To measure productivity from multinational firms, a variable is included that proxies the extent of foreign' firms penetration.... In other words, the regression allows for an effect of FDI on the productivity of firms in the same industry. If the regression analysis yields a positive and statistically significant coefficient of the foreign presence, this is taken as a evidence spillovers have occurred (Görg \& Greenaway, 2004, p. 176).

Based on Gachino's (2010) model for determinants of spillover and studies using meta-analysis methodology developed by Görg and Strobl (2001), Görg and Greenaway (2004), and Wooster and Diebel (2010), we outline the determinants of spillover occurrence in a broad conceptual model, as presented in Figure 2.

Theory on FDI spillovers states that, especially in developing countries, their occurrence depends on a number of factors related not only to MNC characteristics, but also to specific characteristics of LOEs in host countries. Furthermore, factors related to industry, region and country characteristics determine FDI spillover occurrence (Gachino, 2010; Görg \& Greenaway, 2004).

According to Gachino (2010),

the occurrence of spillovers does not only depend on the presence of MNCs, but also on absorptive capacity, presence of support structures and institutions, presence of interactions and trade orientation. Other factors include firm size, age, ownership structure, performance, firm strategy and industry structure (Gachino, 2010, p. 203).

The theory suggests some possible mechanisms through which spillovers may occur, such as imitation, worker mobility, competition and linkages, as presented in Figure 2 (Görg \& Greenaway, 2004). However, although presented in the conceptual model, they do not constitute objects of this study and will not be analyzed. Furthermore, analysis of spillover occurrence through these channels requires in-depth analysis and, therefore, qualitative methodologies for collecting and analyzing data would be required. 


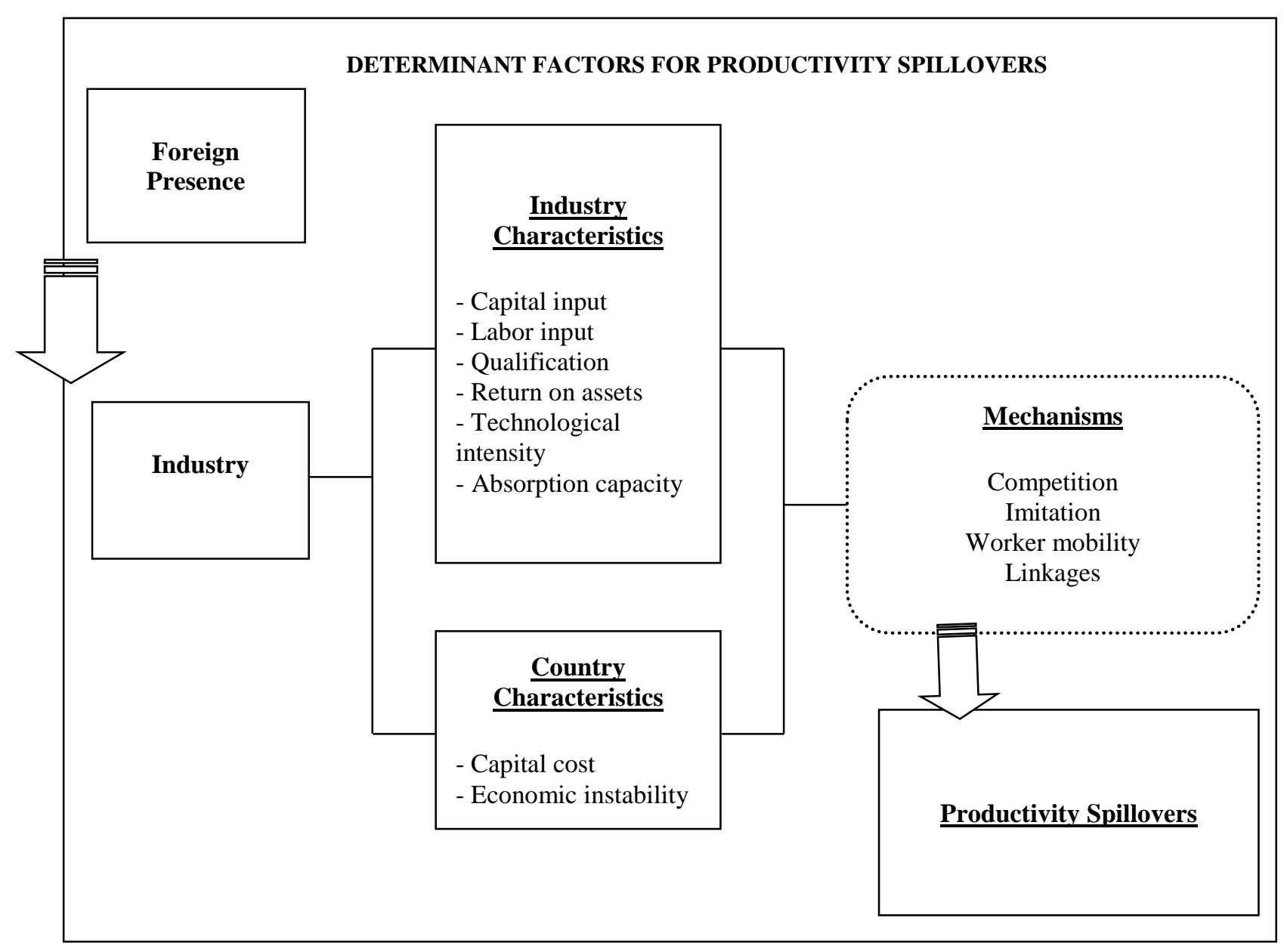

Figure 2. Conceptual Model of Spillover Occurrence.

Aiming to analyze the contributions FDI has on LOE productivity in host countries we have chosen to analyze the following characteristics of the Brazilian processing industries and Brazil itself.

\section{Industry characteristics}

Following previous studies, (Blomström \& Perrson, 1983; Buckley, Clegg, \& Wang, 2010; Caves, 1974; Globerman, 1979; Hale \& Long, 2011; Kokko, 1994), we estimated our function with labor productivity as our dependent variable. According to Buckley, Clegg, Zheng, Siler and Giorgioni (2010, p. 295) "traditional models of economic growth predict that capital accumulation will raise the level of output per worker up to a point of diminishing returns".

Until the 1980s, the neoclassical model for economic growth developed by Solow (1956) were used as a reference for analytical models of per capita income growth determinants over the long term (Marinho \& Bittencourt, 2007). Solow's (1956) main contribution was to formulate a measure of technical progress for per capita output growth, known as total factor productivity (TFP). The measure had as its starting formulating point a Cobb-Douglas production function structure in which the author found the occurrence of significant residuals, measured by the difference between real output growth rates and weighted capital and labor production factor growth rates (Marinho \& Bittencourt, 2007).

Later studies based on Romer's (1986) pioneering contributions, dedicated efforts to include other factors into the production function that could reduce the residual values and suggest a greater contribution by capital, including human capital, to economic growth. One of Romer's (1986) important contributions was to emphasize the simplicity of aggregate growth models and the belief that the "rate of return on investment and the rate of growth of per capita output ... were ... expected to be decreasing functions of the level of the per capita capital stock" (p. 1002). Romer (1986) offered 
an alternative view of' long-term prospects for growth where the rate of investment and the rate of return on capital might increase rather than decrease with increases in the capital stock. He suggested that endogenous technological change was driven primarily by the accumulation of knowledge by forward-looking and profit-maximizing agents (Romer, 1986, p. 1003). Another Romer contribution is presented in the author's belief that "in contrast to models in which capital exhibits diminishing marginal productivity, knowledge will grow without bound" (Romer, 1986, p. 1003).

Capital input importance (including physical and human capital) comes from its ability to generate positive externalities that raise firm productive capacity. It can be used as an accumulated knowledge indicator and experience in the form of learning-by-doing, in which externalities result in increasing returns (Marinho \& Bittencourt, 2007; Romer, 1986).

Thus, human capital is an important driver of productivity and efficiency in business. Just as physical capital, human capital also increases a company's ability to produce goods and services. In fact, organizational efficiency depends on both material capital, accumulated in the form of machinery and equipment investments, and human capital, acquired through investments in education. To Blomström and Kokko (1998), the existing level of capabilities in an industry is essential to knowledge exchange. The authors argue that worker training is considered a determining factor of how local businesses can benefit from new knowledge to become more competitive.

Human capital is considered an important productivity and efficiency stimulant in enterprises. Just as physical capital, human capital also increases an enterprise's ability to produce goods and services. According to Jajri (2007), education and training of a workforce in order to upgrade capabilities and knowledge will result in higher-skilled and more efficient workers, thus leading to better productivity levels.

Capital intensity indicates investments made by firms in machinery, equipments and infrastructure that leads to increases in capital stock and enhanced production capacity. The higher the capital intensity is, the higher level of firm automation and the higher the expected productivity (Buckley, Clegg, Zheng, Siler, \& Giorgioni, 2010).

Labor quality, in this study represented by the qualification variable, indicates the level of labor force capabilities or education. Improvements in a labor force can lead to increases in productivity (Buckley, Clegg, Zheng et al., 2010).

Our discussion suggests the following:

H1: Everything else constant, the higher the capital input, the higher the productivity of the industry.

H2: Everything else constant, the higher the labor input, the higher the productivity of the industry.

H3: Everything else constant, the higher the qualification, the higher the productivity of the industry.

As presented in our previous discussion, the studies that followed Solow's (1956) pioneer contribution to TFP formulation were dedicated to investigate other determinant factors that could reduce the residuals in productivity functions. In our study, we introduce the return on assets, technological intensity, foreign presence and absorption capacity as variables of analyses for industry characteristics and capital cost and economic instability for country characteristics.

Return on assets (ROA), also known as return on investment (ROI) is a profitability index and measures management effectiveness in terms of generating profits from assets (Gitman, 2004). To Assaf (2003), return on assets represents the total return produced by applications of assets. Thus, industries that have higher levels of return on assets may indicate that investments in assets have been used efficiently to generate sales growth and productivity gains. 
We, then, developed the following hypothesis:

H4: Everything else constant, the higher return on assets index, the higher the productivity of the industry.

Aiming to control the heterogeneity between industries in terms of dynamism, technological sophistication and investment in research and development, we incorporated industry technological intensity in our productivity model.

According to Jajri (2007), the development of new products or new technologies allows production methods that result in a shifting of the production frontier upwards. Innovativeness and technological capability are factors that differentiate the various types of organizations and industries and, consequently, affect their economic performances (Reichert, Beltrame, Corso, Trevisan, \& Zawislak, 2011). According to Buckley, Clegg and Wang (2010, p. 197), "the low technology nature of the host industry is thought to exacerbate the severity of negative competitive impact of FOEs presence. Under such conditions, the growth of negative spillover effects can rapidly became dominant when foreign presence" increases beyond some level.

Therefore, the higher the technological intensity, the higher the long-term profitability.

The technological intensity dummy variable was built from a reform in the Economic Activities National Classification (CNAE), based on the methodology proposed by the Organisation for Economic Co-Operation and Development (OECD, 2008), according to the industry level of technological intensity.

Thus, industries were classified into four categories: (a) low-tech intensity industries; (b) medium-high technological intensity industries; (c) medium-low technological intensity industries; (d) and high-tech intensity industries. The sectors as classified into categories are presented in the appendix.

Since technological effort is a critical determinant of productivity growth and international competitiveness, we will consider that:

H5: Everything else constant, the higher the technological intensity, the higher the productivity of the industry.

Productivity spillovers theory affirm that MNCs have productive assets, management and market capabilities, coordinated relationships with suppliers and consumers and reputations that make them superior in terms of knowledge production and management and market techniques. If MNCs have such advantages, then it is expected that their presence can positively influence LOE productivity (Aitken \& Harrison, 1999). Such gains in productivity caused by foreign influence are called productivity spillovers (Blomström \& Kokko, 1998).

As discussed above, "FDI not only transfers capital but also technologies, managerial capabilities and advanced production functions. Therefore, the greater the foreign investments inflows, the higher productivity will be" (Buckley, Clegg, Zheng et al., 2010, p. 296).

However, spillover effects don't occur automatically (Narula, 2002). When a firm sets up a plant overseas or acquires a foreign plant, it does so with the expectation of realizing a higher rate of return than a given home country firm with an equivalent investment. The source of the higher return is the technological advantage, including innovative management and organizational processes as well new production methods and technologies. Therefore, multinational firms will not simply hand over the source of their advantage (Görg \& Greenaway, 2004). In addition, MNCs are profit-driven and, therefore, are not interested in creating a knowledge transfer environment without receiving a good reward in exchange. For this reason, there are some potential costs associated with FDI inflows, such as an increase in unemployment and the emergence of more concentrated market structures, especially in economies in transition and developing countries (Appleyard \& Field, 1998). 
Empirical research all over the world (Görg \& Strobl, 2001) has shown that evidence on positive spillovers are contradictory or mixed and both empirical and theoretical studies have focused on explaining these mixed results (Thang, 2011). The author argues that an important conclusion of such studies is that the signal and magnitude of productivity spillovers depend on the nature of firms and industries and the conditions of host countries. Cohen (2007) arguments that FDI is a complex and heterogeneous phenomena and that different kinds of businesses produce different kind of corporate activity and, consequently, different results. The nature, objectives and effects of specific kinds of firms in one industry are not applicable to others.

This discussion brings the following hypothesis:

H6: Everything else constant, the higher the foreign presence, the higher the productivity of the industry if there are spillover effects from FDI; or the higher the foreign presence the lower the productivity of the industry.

Studies point out absorption capacity as an important FDI spillover determinant factor. For Cohen and Levinthal (1990), the absorption capacity is the ability to recognize the value of a new knowledge, the capacity to assimilate and apply it, based on business purposes. The authors add that absorptive capacity is fundamental to firms innovative capacity development, which is cumulative and depends on various firm characteristics, such as employees' individual skills, internal organization and investments in Research and Development (R\&D).

Narula (2002) notes that MNC FDI and operations do not automatically generate positive externalities. MNCs may disseminate a large number of externalities that can easily be assimilated or not, depending on LOE capacity. When MNCs establish a plant overseas or acquire a foreign plant, they do so with the expectation of higher rates of return that could be received if compared to their home country with an equivalent investment. The largest source of return is the technological advantage, including new management processes and new production methods. Thus, MNCs will not simply undo these benefits sources (Görg \& Greenaway, 2004). However, theory suggests that even if a MNC has as main motivation the internalization of technology and its use, this can spread or overflow to firms in the host economy.

Thus, Görg and Greenaway (2004) argue that FDI benefits only occur when LOEs have the ability to learn, as well as the capabilities and abilities to imitate MNCs and the internal infrastructure to provide such development conditions. Buckley, Wang and Clegg (2010) argue that positive spillovers are expected for LOEs that have superior absorptive capacity.

Our discussion suggest the following hypothesis:

H7: Everything else constant, the higher the absorption capacity, the higher the productivity of the industry.

\section{Country characteristics}

This group is represented by capital cost and economic instability as variables of analyses to represent country characteristics.

Capital cost represents the price paid to borrow money for a certain period of time. Interest rate behavior affects consumption and investment decisions, external resource flows, exchange rate value and as a consequence, the competitiveness of products from that country. In this study, it is represented by the Selic domestic interest rate, set by the Monetary Policy Committee (Copom) since it has effects on the production structure as it determines the cost of investments (Galeano \& Mata, 2007; Nakabashi, Cruz, \& Scatolin, 2008; Sonaglio, Zamberlan, Lima, \& Campos, 2010).

Interest rates are crucial for industries' productivity level, since they play a decisive role in productive investment decisions. While classical economists emphasized that investments were 
determined solely by the interest rate (Omar, 2008), Keynes (1983) suggested two factors as key determinants of investment spending: the cost of capital, which is the interest rate, and the expected future profitability of investment projects. The higher future profitability is, the higher the level of investments. Thus, when interest rates rise, certain investment projects become impractical (Omar, 2008).

According to the Brazilian Central Bank (Banco Central do Brasil [BACEN], n.d.a), the Selic rate is obtained by calculating the weighted and adjusted average rate of financing transactions for a day, backed by federal government bonds and routed in the referred system or in clearing and settlement systems in the form of repurchase agreements. The origin of the Selic rate is in the interest rates observed in the market and basically reflects the liquidity conditions in the monetary market (supply versus demand for resources) (BACEN, n.d.a).

Then,

H8: Everything else constant, the higher the capital cost, the lower the productivity of the industry.

Economic stability is one of the necessary conditions for entrepreneurs to feel secure in their investment decisions (Galeano \& Mata, 2007). More stable economies with low inflation rates provide industries with better economic performance levels (Damasceno, 2008; Galeano \& Mata, 2007; Lima, 2005; Nonnenberg \& Mendonça, 2005).

To represent economic instability, we use the inflation rate measured by the National Broad National Index of Consumer Price (Índice Nacional de Preços ao Consumidor Amplo [IPCA]). The inflation rate is used as a proxy for the degree of economic instability, given that the classic symptom of loss of control in an economy, both fiscal and monetary, is uncontrolled inflation (Nonnenberg \& Mendonca, 2005).

Hence, the following hypothesis is suggested:

H9: Everything else constant, the higher the economic instability, the lower the productivity of the industry.

\section{Methods and Data}

\section{Econometric model}

The econometric model presented was based on previous studies (Aitken \& Harrison, 1999; Blomström \& Perrson, 1983; Buckley, Clegg \& Wang, 2010; Buckley, Clegg, Zheng et al., 2010; Girma \& Gorg, 2005; Globerman, 1979; Hale \& Long, 2011; Kokko, 1994) aiming to identify FDI effects on the productivity of Brazilian industries. Productivity spillover is usually analyzed in an econometric function in which a number of covariates are assumed to have an effect on productivity, one of which is the foreign presence. The econometric specification identifies spillover effects varying across industries according to their level of absorptive capacity (ABC). Our assumption is that industries with higher absorption capacity will be able to obtain advantages of foreign presence given their abilities to recognize and assimilate new knowledge. Aiming to investigate the spillover effects of FDI depending on the absorptive capacity of industries we developed our main total factor productivity (TFP) function as follows:

$$
\mathrm{TFP}_{\mathrm{it}}=\beta_{1} \mathrm{~K}_{\mathrm{it}}+\beta_{2} \mathrm{~L}_{\mathrm{it}}+\beta_{3} \mathrm{FDI}_{\mathrm{it}}+\beta_{4} \mathrm{ABC} * \mathrm{FDI}_{\mathrm{it}}+\beta_{5} \mathrm{~K}_{\mathrm{it}} * \mathrm{FDI}_{\mathrm{it}}+\beta_{6} \mathrm{~L}_{\mathrm{it}} * \mathrm{FDI}_{\mathrm{it}}+\Gamma \mathrm{Z}_{\mathrm{it}}+\Pi_{\mathrm{it}}+\varepsilon_{\mathrm{it}}
$$

in which $\beta_{1}, \beta_{2}, \beta_{3}, \beta_{4} \beta_{5}$ e $\beta_{6}$ are the parameters to be estimated; $K_{i t}$ is the capital input in industry $i$ at time $t ; L_{i t}$ is the labor input in industry i at time $t ; \beta_{3}, \beta_{4}, \beta_{5}$ and $\beta_{6}$ are FDI spillover effects; FDI $\mathrm{I}_{\mathrm{it}}$ is the 
measure of foreign presence in industry $i$ at time $t ; \Gamma=$ set of parameters related to other characteristics of the industry to be estimated; $Z_{i t}=$ set of variables that capture other specific characteristics of the industry in time i; $\Pi=$ set of parameters related to characteristics of the country to be estimated; $\mathrm{H}_{\mathrm{it}}=$ set of variables that capture specific characteristics of the country at time $i ; \varepsilon_{\text {itc }}=$ the random term error.

The $\beta_{4}$ coefficient measures the spillover effects arising from FDI depending on the absorption capacity of industries while $\beta_{5}$ and $\beta_{6}$ coefficients represents respectively, spillover effects arising from FDI depending on the capital and labor-intensity of industries. If the estimated coefficients turn out to have a positive and statistically significant sign, this is taken as spillover evidence.

Industry absorptive capacity $(A B C)$ is defined as:

$$
\mathrm{ABC}_{\mathrm{it}}=\mathrm{TFP}_{\mathrm{it}} / \max _{\text {industry }}\left(\mathrm{TFP}_{\mathrm{t}}\right)
$$

in which TFP is based on the individual TFP compared to the larger TFP (Kathuria, 2000) with index measures between 0 and 1 . The closer the index is to one, the greater the industry absorption capacity.

The TFP estimation is constructed based on the basic production function described as follows:

$$
\mathrm{Y}_{\mathrm{it}}=\beta_{0}+\beta_{1} \mathrm{~K}_{\mathrm{it}}+\beta_{2} \mathrm{~L}_{\mathrm{it}}+\varepsilon_{\mathrm{it}}
$$

in wich $Y_{\mathrm{it}}$ is industry productivity, measured by the industrial production sector value $\mathrm{i}$ at time $\mathrm{t} ; \beta_{0}$ is the intercept; $\beta_{1}$ e $\beta_{2}$ are parameters to be estimated; $K_{i t}$ is capital input, in industry i at time t; $L_{i t}$ is labor input in industry $\mathrm{i}$ at time $\mathrm{t} ; \varepsilon_{\text {itc }}$ is the random term error. TFP is the share of the dependent variable not explained by the physical quantities of two traditional factors (capital and labor inputs), in other words, the residuals. So, what is not explained by the inputs accumulation, particularly capital and labor, will be explained by the growth of TFP.

The effects of variables related to (a) industry characteristics; (b) country characteristics; (c) foreign presence; and (d) interactions with foreign presence were analyzed using Moderated Multiple Regression (MMR) and Generalized Linear Models (GLM) analysis of variance. We performed the analysis undertaken in this study using SAS statistical software, version 8.

The Moderated Multiple Regression (MMR) involved hierarchical regression to test: (a) Equation 1: the relationship of the primary predictors of interest (industry and country characteristic variables) on the dependent variable; (b) Equation 2: the relationship of the primary predictors of interest (as in Equation 1) plus foreign presence on dependent variable; and (c) Equation 3: the relationship of the primary predictors of interest, foreign presence (as in Equation 2) plus the relationship of foreign presence interaction terms on the dependent variable. The interaction variables incorporated in the model were: (a) capital input * foreign presence; (b) labor input * foreign presence; (c) and absorption capacity $*$ foreign presence. They are used to demonstrate the effect of a given variable depending on the moderating effect of another.

Before estimating the regressions, we conducted a correlation test in order to verify the relationship degree between variables and if there were problems associated with multicollinearity. The method used to measure the association degree between variables in this study was Pearson correlation coefficient. We used the tolerance (TOL) and variance inflation factor (VIF) as complementary measure to detect multicollinearity.

We verified the autocorrelation presence in error terms through scatter plot of predicted values in relation to waste diversion. According to Gujarati (2006), residual graphical analysis offers a simple summary to understand a complex problem. They allow a simultaneous examination of individual cases, while showing data behavior as an aggregate. Autocorrelation premise is related to population error terms, which cannot be directly observed. What we usually have are residuals, which are proxies that can provide evidence about autocorrelation in error terms presence (Gujarati, 2006). 
Adjustment analysis in Generalized Linerar Models is based on statistical deviance. To do so, we followed Allison's (2001) instructions. In general, the smaller the deviation value, the better the model fits the data.

Two other measures commonly used in model adjustment analysis were used in this study: Akaike Information Criterion (AIC) and Schwartz. The statistical AIC is obtained by adding $2 \mathrm{k}$ to the deviation, where $\mathrm{k}$ represents the number of model parameters (Allison, 2001). The statistical Schwartz is obtained by adding $\mathrm{k} \log \mathrm{n}$ to the deviations ( $\mathrm{n}$ represents the sample size). In general, when comparing two or more models, the best one is the one that shows the lower values of these statistics.

\section{Description of variables}

The series used in the analysis have panel database form and contain aggregate data on twentythree intentionally chosen Brazilian processing industries, defined by the National Code of Economic Activities (CNAE). A description of variables and their expected signs are summarized in Table 1.

Table 1

List of Selected Variables Description and Their Expected Signs

\begin{tabular}{|c|c|c|}
\hline Variable & Description & Expected signs \\
\hline \multicolumn{3}{|c|}{ Dependent variable } \\
\hline Productivity (PROD) & $\begin{array}{l}\text { Industrial transformation value divided by the number of } \\
\text { people employed in the industry. }\end{array}$ & \\
\hline \multicolumn{3}{|c|}{ Characteristics of the industry } \\
\hline Capital input (CAP) & Total assets of the industry. & + \\
\hline Labor input (TRAB) & $\begin{array}{l}\text { Number of people employed in the industry, including } \\
\text { salaried people with or without employment }\end{array}$ & + \\
\hline Qualification (QUAL) & $\begin{array}{l}\text { Ratio of total gross wages paid by the industry to the } \\
\text { number of people employed in the same industry }\end{array}$ & + \\
\hline Return on assets index (IROA) & $\begin{array}{l}\text { Ratio of sales operating revenue in the industry in relation } \\
\text { to its total assets }\end{array}$ & + \\
\hline Technological intensity (INTEC) & $\begin{array}{l}\text { Dummy variable representing industry technological } \\
\text { intensity based on four categories: (1) low-tech intensity } \\
\text { industries; (2) medium-high technological intensity } \\
\text { industries; (3) medium-low technological intensity } \\
\text { industries; (4) and high-tech intensity industries }\end{array}$ & \\
\hline Foreign presence (FDI) & $\begin{array}{l}\text { Flows of foreign direct investment (FDI) received by the } \\
\text { industry }\end{array}$ & $+/-$ \\
\hline Absorption capacity (CAPAB) & The individual TFP compared to the larger TFP & + \\
\hline \multicolumn{3}{|c|}{ Country Characteristics } \\
\hline Capital cost (CUSTOCAP) & Internal Selic interest rate proxy variable & - \\
\hline Economic instability (INSTEC) & $\begin{array}{l}\text { Inflation rate, measured by the National Consumer Price } \\
\text { Index (IPCA) }\end{array}$ & - \\
\hline
\end{tabular}

Productivity, capital input, labor input, qualification and rate of return on assets variables were obtained from the Annual Industrial Research (PIA) database, released by Instituto Brasileiro de Geografia e Estatística (IBGE, 2005). The scope of the PIA sectoral aggregated database includes companies that meet the following requirements in December 31 of the reference year: (a) be in active 
status in Enterprises Central Register (CEMPRE) from IBGE; (b) have a main economic activity classified in C (Extractive industries) or D (Processing Industries) sections from CNAE classification; (c) be headquartered anywhere in Brazil; (d) have five or more employees. The sample is obtained by simple stratified sampling. Surveyed companies are part of a census selection form for the universe of companies with 30 or more employees. A random stratum identifies companies with 5 to 29 people employed, randomly selected without replacement.

FDI inflows, classified according to the CNAE classification, were obtained from the Foreign Capital Census of Brazil's Central Bank (BACEN, n.d.b). The Selic rate and IPCA inflation rate were obtained from Institute of Applied Research (Instituto de Pesquisa Econômica Aplicada [IPEA], 2011) database.

Since not all industries presented available data for all years, it became necessary to exclude some observations from the sample. Furthermore, as some continuous variables showed significant amplitude, we used logarithmic transformation in order to reduce their amplitudes. Thus, these variables will be incorporated into the analysis in logarithmic form.

\section{Results}

Pearson correlation results showed that some variables such as capital input, labor input and foreign presence were correlated (Table 2). However, as these variables were essential to the productivity function, we could not simply exclude these variables from the models. So, we used the tolerance (TOL) and variance inflation factors (VIF) as complementary measures to detect multicollinearity.

Table 2

Pearson Correlation Test Selected Variables

\begin{tabular}{|c|c|c|c|c|c|c|c|c|}
\hline & 1 & 2 & 3 & 4 & 5 & 6 & 7 & 8 \\
\hline \multirow{2}{*}{$1 \mathrm{a}$} & \multirow{2}{*}{1,00} & 0,6094 & 0,7225 & 0,1498 & $-0,470$ & $-0,386$ & 0,005 & 0,185 \\
\hline & & $<, 0001$ & $<, 0001$ & 0,1562 & $<, 0001$ & 0,0002 & 0,996 & 0,078 \\
\hline \multirow{2}{*}{$2 b$} & & \multirow{2}{*}{1,00} & 0,6667 & $-0,237$ & $-0,062$ & $-0,629$ & 0,002 & 0,004 \\
\hline & & & $<, 0001$ & 0,0235 & 0,5548 & $<, 0001$ & 0,998 & 0,970 \\
\hline \multirow{2}{*}{$3 c$} & & & 100 & 0,2856 & 0,0024 & $-0,254$ & $-0,104$ & $-0,094$ \\
\hline & & & 1,00 & 0,0064 & 0,9817 & 0,0155 & 0,325 & 0,376 \\
\hline \multirow{2}{*}{$4 d$} & & & & 100 & 0,0852 & 0,5618 & 0,081 & 0,107 \\
\hline & & & & 1,00 & 0,4216 & $<, 0001$ & 0,445 & 0,309 \\
\hline \multirow{2}{*}{$5 e$} & & & & & 100 & 0,0976 & 0,0666 & $-0,333$ \\
\hline & & & & & 1,00 & 0,3573 & 0,529 & 0,001 \\
\hline \multirow{2}{*}{$6 f$} & & & & & & 100 & $-0,002$ & 0,020 \\
\hline & & & & & & & 0,979 & 0,843 \\
\hline \multirow{2}{*}{$7 \mathrm{~g}$} & & & & & & & 1.00 & 0,630 \\
\hline & & & & & & & & $<, 0001$ \\
\hline 8hi & & & & & & & & 1,00 \\
\hline
\end{tabular}

Note. ${ }^{\mathrm{a}}$ Capital input; ${ }^{\mathrm{b}}$ Labor input; ${ }^{\mathrm{c}}$ foreign presence; ${ }^{\mathrm{d}}$ qualification; ${ }^{\mathrm{r}}$ eturn on assets; ${ }^{\mathrm{f}}$ technological intensity; ${ }^{\mathrm{g}}$ cost of capital; heconomic instability. 
The results showed that for all three analyzed equations, TOL and VIF values were within acceptable limits and do not denote collinearity, indicating that the results are reliable.

Then, we verified the autocorrelation presence in error terms through scatter plot of predicted values in relation to waste diversion (Figure 3). Since there was no observed trend pattern from predicted observations related to residuals deviation for the proposed models, we can say that there is no residuals' heteroscedasticity evidence and, therefore, the models are appropriate.

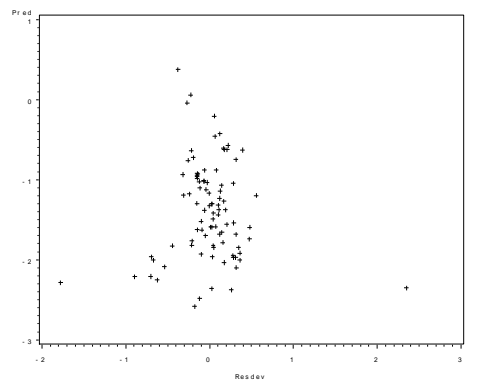

(a) Equation 1

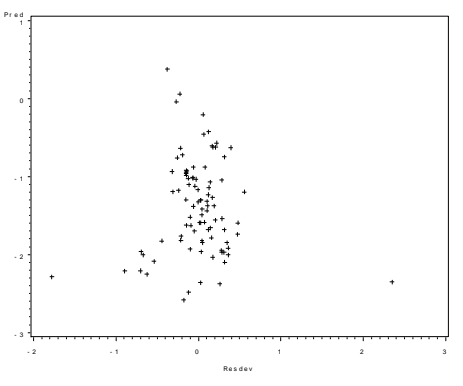

(b) Equation 2

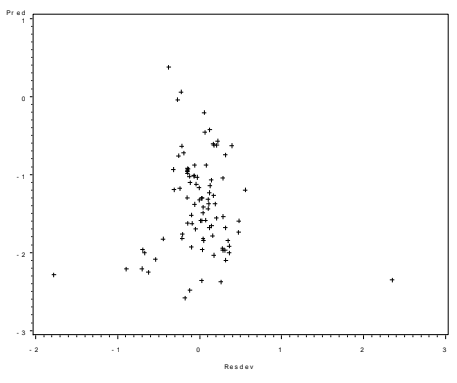

(c) Equation 3

Figure 3. Predicted Values for Waste Deviations for Proposed Equations.

Table 3 presents the results for the proposed equations containing the individual parameters, deviations, Akaike Information Criterion (AIC),Schwartz, R-Square and F-Value statistics. Based on results, we can say that Equation 3, which includes industry and country characteristics, as well as foreign presence and interactions with foreign presence, presented the best adjustment.

Table 3

Estimates for Productivity Models

\begin{tabular}{|c|c|c|c|}
\hline Parameters & Equation (1) & Equation (2) & Equation (3) \\
\hline INTERCEPTO & $-5.5474 * * *$ & $-6.0530 * * *$ & $3.7388 * * *$ \\
\hline ICAP & $0.6438 * * *$ & $0.6912 * * *$ & 0.0503 \\
\hline ITRAB & $-0.5879 * * *$ & $-0.5919 * * *$ & $0.1479 * *$ \\
\hline QUAL & 0.1295 & 0.1264 & 0.0947 \\
\hline IROA & $0.9599 * * *$ & $1.0035^{* * *}$ & $0.0110 * * *$ \\
\hline INTEC 0 & 0.1136 & 0.0778 & $0.1870^{* *}$ \\
\hline INTEC 1 & 0.0342 & 0.0317 & $0.0806 * * *$ \\
\hline CUSTOCAP & -0.2839 & -0.3301 & -0.1434 \\
\hline INSTEC & 0.0048 & 0.0065 & 0.0019 \\
\hline FDI & & -0.0361 & 0.4355 \\
\hline FDI*ICAP & & & 0.00222 \\
\hline FDI*ITRAB & & & $-0.0233^{* *}$ \\
\hline FDI*CAPAB & & & $0.1797 * * *$ \\
\hline Deviance & 15,38 & 15,21 & 2,32 \\
\hline AIC & 31,38 & 33,21 & 26,32 \\
\hline Schwartz & 31,05 & 32,84 & 25,82 \\
\hline R-Square & 0,6082 & 0,6054 & 0,9342 \\
\hline F-Value & $15.91 * * *$ & $13.54 * * *$ & $100.69 * * *$ \\
\hline
\end{tabular}

Note. $* * *$ Significant at $1 \%, * *$ significant at $5 \%, *$ significant at $10 \%$ 
The results for equation 1 showed that the positive relationship between the capital input variable (ICAP) and dependent variable productivity (PROD) is consistent with proposition 1 (P1), indicating that the higher the levels of capital input, the greater the productivity of industries.

Labor input variable (ITRAB) was negatively related to the dependent variable and inconsistent with proposition 2 (P2) indicating that the higher the labor input the less productivity is the industry.

Rate of return on assets variable (IROA) was statistically significant at $1 \%$ and positive related to dependent variable, as expected (See Proposition 4). The result is consistent with theory, indicating that industries that optimize their assets generate more productive profits.

The result for the technological intensity variable (INTEC) is consistent with literature and with $\mathrm{H} 5$, suggesting that higher levels of productivity is related with high-technology intensity industries, suggesting that a minimum level of technological sophistication is required so that industries can provide significant levels of productivity.

The next step consisted of estimating Equation 2, which includes, besides variables presented in Equation 1, the foreign presence variable. Results presented for the estimated equation indicate that, for the period analyzed, there is no evidence of productivity spillover occurrence resulting from foreign presence in analyzed industries. Furthermore, the variable incorporation demonstrates no significant changes in direction and significance levels of other variables.

Finally, we incorporated the interaction variables with foreign presence in Equation 3. Results presented for Equation 3 show that Labor input (ITRAB) became positive and coherent with our expectations presented in $\mathrm{H} 2$ showing that the higher the labor input, the higher the industry productivity. When analyzing results obtained from Labor input (LNITRAB) with foreign presence interaction (FDI), we found an inverse relationship, indicating that FDI entry in labor intensive industries provides fewer productivity gains.

Interaction of the foreign presence variable (FDI) with absorption capacity (CAPAB) was incorporated into the model in order to test the effect of foreign presence depending upon the moderating effect of industry absorption capacity. The results found for this interaction indicated a positive relationship in the order of 0.1797 and statistically significant at $1 \%$, confirming the hypothesis that FDI presence benefits depends on industry absorptive capacity.

\section{Discussions}

Results for proposed equations showed a positive relationship between capital input (ICAP), and rate of return on assets (IROA) variables with the dependent variable productivity (PROD). Those results are consistent with our propositions and demonstrated that these variables are directly related with productivity of studied industries. However, the results obtained for labor input (ITRAB) variable differ from what we expected in $\mathrm{H} 2$ in Equation 1 and 2 and can be justified by the fact that labor intensive industries may use their labor input investments to generate higher levels of productivity inefficiently. This means that, although the new investments in labor input may create or expand their production capacity, they do not necessarily expand their capacity to generate outputs and, thus, become more productive.

The technological intensity (INTEC) variable suggests that high-technology intensity industries are more productive. The results indicate that the higher the technological sophistication and dynamism, the higher the productivity of a given industry.

Results for Equation 2 showed that when incorporating foreign presence (FDI) in Equation 2 we find no evidence of productivity spillover from foreign presence. Evidence shows that, although it is undeniable that foreign presence can lead to technology diffusion, it is noteworthy that the transfer of 
this technology to LOEs does not happen automatically. Moreover, one cannot lose sight of the difference between learning technology and operational creation of a new technology. FDI can be effective in transferring the result of innovation, but not necessarily the ability to innovate.

Furthermore, when a MNC establishes a plant overseas or acquires a foreign plant, it does so in the expectation of higher rates of return that could receive, compared to their home country, with an investment equivalent (Narula, 2002). The largest source of return is in technological advantages, including new management processes and new production methods. Thus, ETNs will not simply get rid of their benefits sources (Görg \& Greenaway, 2004).

The result is not necessarily inconsistent with theory since there may be negative spillover effects in some industries, while others present positive effects. To answer this question, we included FDI interaction variables aiming to understand if there are any variation of FDI effects depending on specific industry characteristics.

Equation 3 showed that, when analyzing results from labor input we found a positive relation as expected in $\mathrm{H} 2$ but different from results for Equation 1 and 2. They suggest that Brazilian laborintensive industries can use their labor input investments to generate higher levels of productivity, but when ITRAB interacts with FDI we found negative effects of labor inputs on industry productivity. One plausible explanation for negative results is presented by Görg and Greenaway (2004), Aitken and Harrison (1999) and Buckley, Clegg and Wang (2010). They argue that, at a greater level of foreign presence, MNC negative effects start to become apparent as foreign firms may reduce LOE productivity through competition effects. According to them, MNCs usually have lower marginal costs due to firm specific advantages, which allows them to attract demand away from LOEs through the introduction of innovation processes and differentiated products. Labor-intensive industries may not be prepared to compete with them. Furthermore, competing with MNCs may require technologies and organizational processes that are very specific and require higher levels of investments, which may include, in addition to the purchase of machinery and latest equipment, staff training and research and development $(R \& D)$ investments, that are not practical for LOEs in labor-intensive industries.

Another explanation for negative spillover effects of FDI in labor-intensive industries is presented by Blomström and Kokko (1998) and emphasizes that, if the home country's labor force is well educated and wages are relatively higher, the structural shift is likely to bring emphasis on production in advanced industries with high labor productivity in the home country. Thus, the simple production processes requiring lots of unskilled labor may be moved to foreign affiliates, leading to lower levels of productivity in the industry. Thus, industries with higher foreign presence will have lower productivity levels.

It is evident that MNC presence can also induce a reduction in the number of companies in the industry, since when competing with MNCs, less efficient domestic firms may be forced to cease operation (Blomström \& Kokko, 1998).

However, Caves (1971) adds that, whatever the market structure resulting from FDI influence, it is argued that a MNC's entry tends to induce more active competitive behavior than would the entry of a domestic company with the same initial scale. Even if a MNC has as its main motivation the technology use internationalization, it can spread or spillover for firms in the host economy.

Our results are consistent with theory and show that firms' absorptive capacity have shown to be a determinant factor for FDI spillover occurrence, evidence that can be confirmed by the results of foreign presence (FDI) and absorption capacity (CAPAB) interaction. The evidences show that FDI benefits depend on industry absorptive capacity and that not all industries should be expected to benefit equally from foreign presence spillovers. According to the literature, host industries must possess high absorptive capacity to obtain the advantages from foreign presence (Blomström, Globerman, \& Kokko, 1999; Castellani \& Zanfei, 2003; Girma \& Gorg, 2005; Haddad \& Harrison, 1993; Hale \& Long, 2011; Kathuria, 2000; Kokko, 1994; Malik, Rehman, Ashraf, \& Abbas, 2012). The entry of MNCs in industries with high absorption capacity may lead to an increase in the 
competition level between companies, forcing them to become more efficient. Increased competition that occurs in the presence of MNCs is considered a knowledge intensifier diffusion mechanism by increasing competitive pressure, in particular if it induces industries to use existing resources more efficiently.

\section{Final Considerations}

This paper finds evidence of the coexistence of both positive and negative effects arising from FDI on Brazilian industries' productivity. Our findings suggest that inward FDI leads to positive spillover effects in high absorption capacity industries and negative effects in labor-intensive industries.

Finding that spillovers do not occur equally in all industries leads to questions related to unconditional or unrestricted FDI liberalization policies. The results confirm Buckley, Clegg and Wang (2010) findings that the "complexity of spillover effects challenges the laissez-faire view that all inward FDI into all types of industries is equally valuable in terms of productivity spillover benefits" (Buckley, Clegg, \& Wang, 2010, p. 192).

The results are similar to Cohen's (2007) findings that FDI sometimes has positive effect, but sometimes negative, neutral or irrelevant effects. According to the author, subsidiaries of MNCs operating in different national and regional environments generate effects that ranges from highly deleterious to high beneficial. To the author, no two MNCs are organized alike and share the same production profile, even subsidiaries of the same company will never be identical in their output and impact on the host economy. They have different business cultures and produce different effects on host economies.

Based on the following arguments presented by Cohen (2007), our comprehension is that: (a) different kinds of businesses produce different kinds of corporate activity; and (b) the nature, objectives and effects of specific kinds of firms in different industries and countries are not applicable to others. So, based on Cohen (2007) arguments, we suggest not using the good-versus-bad approach, since it can be superficial at best and inaccurate at worst. We defend the thesis of the heterogeneity in FDI effects and the imperative of disaggregation in studies in the various levels of analysis, including the individual manager, the firm, the industry and the environment. In each category there is a vast heterogeneity of issues to be discussed and comprehended (Buckley \& Lessard, 2010, p. 7).

Our findings yield original insights into the complexity of spillover effects FDI into Brazilian industries and brings into discussion the need for a deeper understanding of its possible causes (Buckley, Clegg, \& Wang, 2010, p. 192) and the necessity of well defined and structured sectoral policies seeking to attract higher quality FDI that can effectively contribute to Brazilian industry competitiveness and national industry development.

Our evidence's implication is that policymakers should appreciate both the critical need to preserve and maximize competition among MNCs and LOEs and the need to achieve at least a minimum level of domestic technological capability and technical education (Buckley, Wang, \& Clegg, 2010; Cohen, 2007); comprehending that there is no way to stop MNCs from growing and increasing their market shares as they respond to market competitiveness. This doesn't mean that a passive government compliance is desirable, but they should consider looking at the ways in which initially disadvantaged LOEs could be helped in acquiring the necessary capabilities to compensate their disadvantages. This might occur, for example, through and public-private partnership seeking a closer approximation with MNCs and through an increase in vigorous enforcement laws.

The analyses bring implications for policymakers, as suggested by Buckley and Ruane (2010): (a) it is important that policy makers understand that MNC strategies are not only local or regional, but global. Host countries need to focus on what immobile resources they can offer to combine with MNC 
resources to achieve synergy that can benefit industries in the host country; (b) sectoral directions require selectivity projects, considering a careful cost-benefit analysis and strategic bargaining; (c) combining both financial and fiscal performance-based incentives designed to ensure outcome benefits to host country LOEs; (d) monitoring project outcomes.

Study limitations can be highlighted due to the fact that, given the nature of the object of the study and database unavailability, the channels and other important variables determining spillover occurrence could not be incorporated in the model, such as systemic interactions among agents arising from networks and other forms of informal linkages, infrastructural and institutional support structure and some specific firm characteristics, such as firm size-scale, R\&D investments, firm strategy, proximity with MNCs and regional characteristics could not be analyzed in this study.

As suggestion for future studies we recommend a research agenda in both quantitative and qualitative terms such as: (a) the relationship between different kinds of foreign investment strategies by certain kinds of FOEs and the increases in LOE economic performance and innovation capacity; (b) how human capital, natural, economic and political environments are related to the success or failure of FDI benefits on LOEs of host countries; (c) which variables can determine whether a FDI project is beneficial to host economies or not, and which benefits can be achieved through public policies. We expect that the disaggregation and in-depth appreciation of these heterogeneous, complex and dynamic phenomena can lead to many other accurate insights into the subject.

\section{References}

Aitken, B., \& Harrison, A. (1999). Do domestic firms benefit from direct foreign investment? Evidence from Venezuela. American Economic Review, 89(3), 605-618. doi: 10.1257/aer.89.3.605

Aitken, B., Harrison, A., \& Lipsey, R. E. (1996). Wages and foreign ownership: a comparative study of Mexico, Venezuela, and the United States. Journal of International Economics, 40(3/4), 345371. doi: 10.1016/0022-1996(95)01410-1

Allison, P. D. (2001). Logistic regression using SAS Systems: theory and applications (2nd ed.). Cary, NC: SAS Institute.

Appleyard, D. R., \& Field, A. J., Jr. (1998). International economics. Boston, EUA: Irwin/McGrawHill.

Assaf, A., Neto (2003). Finanças corporativas e valor. São Paulo: Atlas.

Banco Central do Brasil. (n.d.a). Descrição da taxa Selic. Retrieved from http://www.bcb.gov.br/?SELICDESCRICAO

Banco Central do Brasil. (n.d.b). Investimento estrangeiro direto. Estoque de investimento estrangeiro direto (1950 - Junho/1995). Retrieved http://www.bcb.gov.br/?INVEDIR

Blomström, M. (1986). Foreign investment and productive efficiency: the case of Mexico. Journal of Industrial Economics, 35(1), 97-110.

Blomström, M., Globerman, S., \& Kokko, A. (1999). The determinants of host country spillovers from foreign direct investment: review and synthesis of the literature [Working Paper $\mathrm{N}^{\mathrm{o}}$ 76]. The European Institute of Japanese Studies, Strockholm, Sweden.

Blomström, M., \& Kokko, A. (1998). Multinational corporations and spillovers. Journal of Economic Survey, 12(3), 247-277. doi: 10.1111/1467-6419.00056 
Blomström, M., \& Pearsson, H. (1983). Foreign investment and spillover efficiency in an underdeveloped economy: evidence from the Mexican manufacturing industry. World Development, 11(6), 493-501. doi: 10.1016/0305-750X(83)90016-5

Buckley, P. J., Clegg, J., \& Wang, C. (2010). Is the relationship between inward FDI spillover effects linear? An empirical examination of the case of China. In P. J. Buckley (Org.), Foreign direct investment, China and the world economy (pp. 192-215). London: Palgrave Macmillan.

Buckley, P. J., Clegg, J., Zheng, P., Siler, P. A., \& Giorgioni, G. (2010). The impact of foreign direct investment on the productivity of Chinas automotive industry. In P. J. Buckley (Org.), Foreign direct investment, China and the world economy (pp. 284-304). London: Palgrave Macmillan.

Buckley, P. J., \& Lessard, D. R. (2010). Regaining the Edge for International business research. In P. J. Buckley (Org.), Foreign direct investment, China and the world economy (pp. 7-24). London: Palgrave Macmillan.

Buckley, P. J., \& Ruane, F. (2010).Foreign direct investment in Ireland: policy implications for emerging economies. In P. J. Buckley (Org.), Foreign direct investment, China and the world economy (pp. 365-385). London: Palgrave Macmillan.

Buckley, P. J., Wang, C., \& Clegg, J. (2010). The impact of foreign ownership, local ownership and industry characteristics on spillover benefits from foreign direct investment in China. In P. J. Buckley (Org.), Foreign direct investment, China and the world economy (pp. 305-326). London: Palgrave Macmillan.

Castellani, D., \& Zanfei, A. (2003). Technology gaps, inward investments and productivity of European firms. Economics of Innovation and New Technology, 12(6), 555-576. doi: $10.2139 / \mathrm{ssrn} .276869$

Caves, R. E. (1971). International corporations: the industrial economics of foreign investment. Economica, 38(149), 1-27.

Caves, R. E. (1974). Multinational firms, competition, and productivity in host-country markets. Economica, 41(162), 176-193.

Cohen, S. D. (2007). Multinational corporations and foreign direct investment: avoiding simplicity, embracing complexity. Oxford: Oxford University Press.

Cohen, W. M., \& Levinthal, D. A. (1990). Absorptive capacity: a new perspective on learning and innovation. Administrative Science Quarterly, 35(1), 128-152.

Damasceno, A. O. (2008). Liberalização da conta de capitais e crescimento econômico: evidências de dados em painel para a América Latina. Revista de Economia Política, 28(4), 595-611. doi: 10.1590/S0101-31572008000400004

Dunning, J. H. (2000). The eclectic paradigm as an envelope for economic and business theories of MNE activity. International Business Review, 9(2), 163-190. doi: 10.1016/S09695931(99)00035-9

Dunning, J. H., \& Lundan, S. M. (2008). Multinational enterprises and the global economy (2a ed.). Cheltenham: Edward Elgar.

Fernandes, E. A., \& Campos, A. C. (2008). Investimento direto estrangeiro e o desempenho das exportações brasileiras. Revista de Economia Política, 28(3), 490-509. doi: 10.1590/S010131572008000300008

Findlay, R. (1978). Some aspects of technology transfer and direct foreign investment. American Economic Review, 68(2), 275-279. 
Gachino, G. (2010). Technological spillovers from multinational presence: towards a conceptual framework. Progress in Development Studies, 10(3), 193-210. doi: $10.1177 / 146499340901000301$

Galeano, E. A., \& Mata, H. T. C. (2007). O comportamento do investimento no Brasil no período de 1995 a 2005. Perspectivas Contemporâneas, 2(2), 2-25.

Girma, S., \& Gorg, H. (2005). Foreign direct investment, spillovers and absorptive capacity: evidence from quantile regressions. Paper Discussion, Kiel Institute for World Economics, 1(1248), 1-31.

Gitman, L. J. (2004). Princípios de administração financeira. São Paulo: Pearson.

Globerman, S. (1979). Foreign direct investment and spillover efficiency benefits in Canadian manufacturing industries. Canadian Journal of Economics, 12(1), 42-56.

Görg, H., \& Greenaway, D. (2004). Much ado about nothing? Do domestic firms really benefit from foreign direct investment? World Bank Research Observer, 19(2), 171-197. doi: 10.1093/wbro/lkh019

Görg, H., \& Strobl, E. (2001). Multinational companies and productivity spillovers: a meta-analysis. The Economic Journal, 111(475), 723-739. doi: 10.1111/1468-0297.00669

Gujarati, D. (2006). Econometria básica (4th ed.). Rio de Janeiro: Elsevier.

Haddad, M., \& Harrison, A. (1993). Are there positive spillovers from direct foreign investment? Evidence from panel data for morocco. Journal of Development Economics, 42(1), 51-74. doi: 10.1016/0304-3878(93)90072-U

Hale, G., \& Long, C. (2011). Are there productivity spillovers from foreign direct investment in China? Pacific Economic Review, 16(2), 135-153. doi: 10.1111/j.1468-0106.2011.00539.x

Instituto Brasileiro de Geografia e Estatística. (2005). Pesquisa industrial anual. Retrieved from http://www.ibge.gov.br/home/estatistica/economia/industria/pia/produtos/produto2005/default.s htm

Instituto de Pesquisa Econômica Aplicada. (2011). Ipeadata macroeconômico. Retrieved from http://www.ipeadata.gov.br

Jajri, I. (2007). Determinants of total factor productivity growth in Malaysia. Journal of Economic Cooperation, 28(3), 41-58.

Kathuria, V. (2000). Productivity spillovers from technology transfer to Indian manufacturing firms. Journal of International Development, 12(3), 343-369. doi: 10.1002/(SICI)10991328(200004)12:3<343::AID-JID639>3.0.CO;2-R

Keynes, J. M. (1983). Teoria geral do emprego, do juro e do dinheiro. São Paulo: Abril Cultural.

Kokko, A. (1994). Technology, market characteristics, and spillovers. Journal of Development Economics, 43(2), 279-293. doi: 10.1016/0304-3878(94)90008-6

Kupfer, D., \& Hasenclever, L. (2002). Economia industrial: fundamentos teóricos e práticas no Brasil. Rio de Janeiro: Campus.

Lima, A., Jr. (2005). Determinantes do investimento direto estrangeiro no Brasil (Dissertação de mestrado). Universidade Federal de Minas Gerais, Belo Horizonte, MG, Brasil.

Malik, A. R. A., Rehman, C. A., Ashraf, M., \& Abbas, R. Z. (2012). Exploring the link between foreign direct investment, multinational enterprises and spillover effects in developing 
economies. International Journal of Business and Management, 7(1), 230-240. doi: 10.5539/ijbm.v7n1p230

Marinho, E., \& Bittencourt, A. (2007). Produtividade e crescimento econômico na América Latina: abordagem da fronteira de produção estocástica. Estudos Econômicos, 37(1), 5-33. doi: 10.1590/S0101-41612007000100001

Markusen, J. R., \& Venables, A. J. (1999). Foreign direct investment as a catalyst for industrial development. European Economic Review, 43(2), 335-356.

Meyer, K. E. (2004). Perspectives on multinational enterprises in emerging economies. Journal of International Business Studies, 35(4), 259-276. doi: 10.1057/palgrave.jibs.8400084

Nakabashi, L., Cruz, M. J. V., \& Scatolin, F. (2008). Efeitos do câmbio e juros sobre as exportações da indústria brasileira. Revista de Economia Contemporânea, 12(3), 433-461. doi: 10.1590/S1415-98482008000300002

Narula, R. (2002). Innovation systems and inertia in R\&D location: Norwegian firms and the role of systemic lock-in. Research Policy, 31(5), 795-816. doi: 10.1016/S0048-7333(01)00148-2

Nonnenberg, M. J. B., \& Mendonça, M. J. C. (2005). Determinantes dos investimentos diretos externos em países em desenvolvimento. Estudos Econômicos, 35(4), 631-655. doi: $10.1590 / \mathrm{S} 0101-41612005000400002$

Omar, J. H. D. (2008). Taxa de juros: comportamento, determinação e implicações para a economia brasileira. Revista de Economia Contemporânea, 12(3), 463-490. doi: 10.1590/S141598482008000300003

Organisation for Economic Co-Operation and Development. (2008). Benchmark definition of foreign direct investment. Retrieved from http://www.oecd.org/daf/inv/investmentstatisticsandanalysis/40193734.pdf

Reichert, F., Beltrame, R., Corso, K., Trevisan, M., \& Zawislak, P. (2011). Technological capability's predictor variables. Journal of Technology Management \& Innovation, 6(1), 14-25. doi: $10.4067 / \mathrm{S} 0718-27242011000100002$

Romer, P. (1986). Increasing returns and long-run growth. Journal of Political Economy, 94(5), 10021037.

Sociedade Brasileira de Estudos de Empresas Transnacionais e da Globalização Econômica. (2007, agosto). Fortalecimento da autonomia das agências reguladoras favorece fluxos de investimento direto estrangeiro. Boletim Sobeet, Ano 6(48), 1-3.

Solow, R. (1956). A contribution to the theory of economic growth. The Quarterly Journal of Economics, 70(1), 65-94. doi: 10.2307/1884513

Sonaglio, C. M., Zamberlan, C. O., Lima, J. E., \& Campos, A. C. (2010). Evidências de desindustrialização no Brasil: uma análise com dados em painel. Economia Aplicada, 14(4), 347-372. doi: 10.1590/S1413-80502010000400005

Thang, T. T. (2011). Productivity spillovers from foreign direct investment: what if productivity is no longer a black box? South East Asian Journal of Management, 5(1) 1-18.

United Nations Conference on Trade and Development. (2003). FDI Policies for development: national and international perspectives. New York, NY: United Nations. Retrieved from http://unctad.org/en/Docs/wir2003overview_en.pdf 
United Nations Conference on Trade and Development. (2007, outubro). Crescimento pulverizado do investimento direto estrangeiro em 2006. Anais da Conférence des Nations Unies Pour le Commerce et le Développement, Geneva, Switzerland.

Wooster, R. B., \& Diebel, D. S. (2010). Productivity spillovers from foreign direct investment in developing countries: a meta-regression analysis. Review of Development Economics, 14(3), 640-655. doi: 10.1111/j.1467-9361.2010.00579.x 


\section{APPENDIX}

Technological intensity of industries was classified into four categories:

1. Low-tech intensity industries: food product and beverage manufacture, tobacco product manufacture, textile manufacture, apparel and accessory article manufacture; leather preparation and leather goods manufacture, travel article, wood product manufacture, pulp manufacture, paper products and recycling.

2. Medium-low technological intensity industries: rubber and plastic product manufacture, coke manufacture, refined petroleum, nuclear fuel development and alcohol production; metallurgy, metal product manufacture - except for machinery and equipment, and other transport equipment construction and vessel repair manufacture.

3. Medium-high technological intensity industries: electrical machinery and equipment manufacture, motor vehicle manufacture, trailers and bodies, chemical and pharmaceutical manufacture, railroad equipment and transport equipment manufacture.

4. High-tech intensity industries: pharmaceuticals, office machinery and computer equipment manufacture, electronic material and communication equipment manufacture, instrumentation equipment and medical manufacture, precision instruments and industrial automation optical equipment, timers and clocks, electronic and communication equipment and apparatus manufacture. 